\title{
Relevance of Epistemological Pluralism for Resource Management Policies
}

\author{
Mónica Gómez Salazar \\ Department of Philosophy, Universidad Nacional Autónoma de México, Ciudad Universitaria, Coyoacán, México \\ Email: monigomi73@yahoo.com
}

Received 11 June 2015; accepted 20 July 2015; published 23 July 2015

Copyright (C) 2015 by author and Scientific Research Publishing Inc. This work is licensed under the Creative Commons Attribution International License (CC BY). http://creativecommons.org/licenses/by/4.0/

(c) $)$ Open Access

\begin{abstract}
The common believe of a single successful form of knowing the reality is misleading. A brief analysis of many human activities reveals a pluralistic perspective of several coexisting conceptual schemes that underlie the form in which women and men know and constitute the world in which we live. Here, I will discuss the necessity of taking seriously this pluralistic perspective when developing conceptual frameworks of human activities. As an example of great interest and importance, I will consider the case of resource management that has to contemplate the conservation and the response of ecosystems to human activities that may lead to irreversible damage. Ecosystems' activity occurs over a wide range of space and time scales and, hence, policies and proposals of solutions to ecological problems should avoid narrow and monochromatic approaches. Specifically, the Pemon perspective of fire is a good example to show that for more robust and flexible resource management we need the knowledge and experience of different cultural and disciplinary groups.
\end{abstract}

\section{Keywords}

Intercultural Policies, Pemon Perspective of Fire, Pluralistic Perspective, Resource Management

\section{Introduction}

An instrumental stance on natural resources has offered us a vision according to which there is a total separation between human beings and nature, and the latter could be manipulated by men for any purpose. This stance conflicts with the lifestyles of indigenous communities in which the world is understood as a living space rather than mere property.

The recognition that there is no single method to obtain valid knowledge is based on a pluralistic understanding of knowledge. This pluralistic stance enables communication and cooperation between groups. Communica- 
tion between groups, which include members of different disciplines, scientific communities and cultures, is required to increase certainty in our epistemic (knowledge-generating) and social practices.

In the particular case of Pemon indigenous people, respect for cultural diversity is important because it is in indigenous communities and towns where coexistence with regional biodiversity has led to the experimentation and development of the use of plants, insects and animals as food, medicine, clothing, personal hygiene and housing (Castillo \& Toledo, 2000; Toledo \& Barrera-Bassols, 2008).

The knowledge of these communities can improve and help promote the conservation of ecosystems and help us survive (Berkes \& Berkes, 2009; Berkes et al., 2000; Olsson et al., 2004; Turner et al., 2003). Of course, this statement does not mean that traditional knowledge is infallible or that it should be assimilated into scientific knowledge (Moller et al., 2004). My claim is that policies transform our existence conditions; therefore, to prevent partial and unjust decisions, resource management policies must be derived from a plurality of practices and ways of life. Damage occurs whenever a global-scale strategy is applied to a wide range of contexts without considering the small-scale existence conditions.

\section{Epistemological Pluralism}

Conceptual schemes are social constructs that we make up and change in our interactions with others. These schemes are conditions of possibility to have concepts, knowledge, beliefs, language, norms and values that we need in order to act in the world. The conceptual schemes are assumptions that provide and bound the set of beliefs it is possible to conceive (Kuhn, 2000). The world in which we born has been experiential given by inheritance, embodying the language, beliefs, knowledges, social practices, norms, policies and values of our forebears. As human beings we can transform the world and ourselves in the process by our social practices. That world altered is the one that will find the next generation. For this reason, we are responsible of existence conditions that next generation will received.

We can relate to different conceptual schemes and discover that what exists in relation to one of them may not exist in relation to another. The consequence of this is that different worlds emerge depending on the conceptual scheme adopted. A pluralistic approach to epistemology recognizes that the world is not only social construction, it is also result of the regularity that characterizes the processes determined by reality and, therefore, it imposes restrictions on our actions and our desires. Thus, pluralism differs substantially from radical relativism.

Any knowledge, including scientific knowledge, is configured into the practices of subjects. Since knowledge depends on how we configure it in a context, there is not knowledge that is complete and infallible. All inquiry proceeds within a cultural matrix which is ultimately determined by social practices of human beings and has no secure foundations (Cartwright et al., 1996). The ends of any research must be judged in relation with its possible consequences on the physical, biological, ecological, social, cultural, moral, political and economic existence conditions in which the subjects live. These conditions are the means by which the end in view is implemented. Once the ends in view are performed and they become effective results, they also become part of the conditions of life that comprise the world of those subjects (Dewey, 1938). In this sense, as epistemic and political subjects we construct the world in which we live, therefore we are partly responsible for it.

Given this diversity of knowledge we can ask how we know that a particular policy of resource management is the more suitable in a given condition. It is necessary to pay attention to the practical consequences. Given that any knowledge is configured in the social practices of subjects and their epistemic practices (generating knowledge practices), the degree of effectiveness of certain practices in particular conditions, indicates that we can increase or decrease our confidence that our policies, justifications, models and experiments will be accurate. Indigenous Peoples who live off wildlife, fish, and forests, also create knowledge from their own observations and ecological understanding, based on the accumulation of generations of trial-and-error experience (Berkes \& Folke, 2002). These epistemic practices are not expressed in scientific language and are not guided by the values and beliefs of scientific communities, however, practices of indigenous people can be correct.

\section{Pemon Knowledge of Fire}

An illustration of this pluralistic coexistence of conceptual schemes is the case of Pemon indigenous people. For decades managers have tried to eliminate savannah burning practices by the Pemon indigenous people in the Canaima National Park known as the Gran Sabana, on the assumption (the managers' belief) that Pemon practices of fire management causes forest loss (Rodríguez, 2004). Against this belief, Pemon elders advocated 
that repeated burns of small portions of the savannah serve as natural firebreaks. Their approach is to fight fire with fire, not with water. In the traditional Pemon knowledge large fires can be prevented by collaboratively burning a mosaic of small portions of savannah in different stages of succession. In such a mosaic, fires die out naturally when they reach the border of a previous fire (Rodríguez, 2007). They know that fires in the area do not have an annual frequency, but occur every three or four years and, rarely, every two years, because of the slow recuperation of the vegetation, which generates in practice a mosaic of savannah patches with different histories of fire (Rodríguez et al., 2009).

Until now, there is considerable scientific uncertainty wether or not the use of fire has been caused a real process of expansion of the savannah at the expense of the forests (Dezzeo et al., 2004; Rull, 2009). On the other hand, Pemon people never cite fire as the specific explanation for the reduction in forests useful for agriculture. They attribute the conversion of forests to savanna vegetation to the concentration of population centers and their growth, which has led to the intensification of a formerly extensive agricultural system. From a pluralistic approach, this explanation is at least as valid as the one given by the park manager's and, in addition, is compatible with the knowledge, scientific and traditional, that population centers act as a stressing factor that imposes an alimentary and energetic pressure on the forests. It is very plausible that the more adequate policy for preserving the forest in the Canaima National Park will contemplate the approaches to the problem that we illustrated here. Hence this is an area in which scientific and traditional knowledge could cooperate in order to preserve resources.

\section{Conclusions}

There is no unique knowledge that can offer us foolproof answers, epistemic cooperation is required so that facing results in which there is no experience is possible to respond in cooperation with other subjects of other conceptual schemes while the crisis is still a small disturbance.

In the ecological field, scientific knowledge tends to approach the conditions of uncertainty in rigid and narrow way. Frequently, scientific research follows linear models of identification and conceptualization of problems, as well as data collection, development and test of hypothesis, as if the epistemic subjects could keep aside from physical, biological, chemical, social, economic, political and cultural contexts of existence, or as if it were possible to predict and control all the following effects. However, the prediction and the control that we can access are not only limited by data and scientific resources that we have, but also by the nature of ecological systems. To put it in epistemic terms, what constrains our practices, policies and knowledge are not our inquiries or conceptual resources but the reality. The dynamics of existence contexts is complex, human interactions and ecosystems are in continuous evolution and in these processes the changes can not always be foreseen. We must admit that some of these changes are irreversibly, and hence the only strategy is to adapt to the new altered system (Folke et al., 2010). It requires a more comprehensive, holistic and flexible vision to assume that surprises are inevitable and that knowledge is always incomplete (Gunderson, 2003). Natural systems have great resilience because of diversity within functions and across scales, but resilience is not infinite, hence we need good policies on resources management in order to preserve variability that is the source of sustinable change (Holling et al., 2002; Díaz et al., 2011).

\section{Acknowledgements}

I am grateful to Dr. Iván Santamaría for his comments and suggestions.

\section{References}

Berkes, F., \& Berkes, M. K. (2009). Ecological Complexity, Fuzzylogic, and Holism in Indigenous Knowledge. Futures, 41, 6-12. http://dx.doi.org/10.1016/j.futures.2008.07.003

Berkes, F., \& Folke, C. (2002). Back to the Future: Ecosystem Dynamics and Local Knowledge. In: L. H. Gunderson, \& C. S. Holling (Eds.), Panarchy Understanding Transformations in Human and Natural Systems (pp. 121-146). Washington DC: Island Press.

Berkes, F., Colding, J., \& Folke, C. (2000). Rediscovery of Traditional Ecological Knowledge as Adaptive Management. Ecological Applications, 10, 1251-1262. http://dx.doi.org/10.1890/1051-0761(2000)010[1251:roteka]2.0.co;2

Cartwright, N., Cat, J., Fleck, L., \& Uebel, T. E. (1996). Otto Neurath: Philosophy between Science and Politics. Cambridge: Cambridge University Press. http://dx.doi.org/10.1017/CBO9780511598241

Castillo, A., \& Toledo, V. M. (2000). Applying Ecology in the Third World: The Case of Mexico. Bioscience, 50, 66-76. http://dx.doi.org/10.1641/0006-3568(2000)050[0066:AEITTW]2.3.CO;2 
Dewey, J. (1938). Logic.The Theory of Inquiry. New York: Henry Holt and Company.

Dezzeo, N., Folster, H., \& Hernández, L. (2004). El Fuego en la Gran Sabana. INCI, 29, 409-410. http://www.scielo.org.ve/scielo.php?script=sci_arttext\&pid=S0378-18442004000800001\&lng=es\&nrm=iso

Díaz, S., Quétier, F., Cáceres, D. M., Trainor, S. F., Pérez-Harguindeguy, N., Bret-Harte, M. S., Finegan, B., Peña-Claros, M., \& Poorter, L. (2011). Linking Functional Diversity and Social Actor Strategies in a Framework for Interdisciplinary Analysis of Nature's Benefits to Society. Proceedings of the National Academy of Sciences of the United States of America, 108, 895-902. http://dx.doi.org/10.1073/pnas.1017993108

Folke, C., Carpenter, S. R., Walker, B., Scheffer, M., Chapin, T., \& Rockström, J. (2010). Resilience Thinking: Integrating Resilience, Adaptability and Transformability. Ecology and Society, 15, 20. http://www.ecologyandsociety.org/vol15/iss4/art20/

Gunderson, L. H. (2003). Adaptive Dancing: Interactions between Social Resilience and Ecological Crises. In F. Berkes, J. Colding, \& C. Folke (Eds.), Navigating Social-Ecological Systems. Building Resilience for Complexity and Change (pp. 33-52). Cambridge: Cambridge University Press.

Holling, C. S., Carpenter, S. R., Brock, W. A., \& Gunderson, L. H. (2002). Discoveries for Sustainable Futures. In L. H. Gunderson, \& C. S. Holling (Eds.), Panarchy Understanding Transformations in Human and Natural Systems (pp. 395-417). Washington DC: Island Press.

Kuhn, T. (2000). The Road since Structure. In J. Conantand, \& J. Haugeland (Eds.), The Road Since Structure. Philosophical Essays 1970-1993 (pp. 90-104). Chicago, IL: The University of Chicago Press.

Moller, H., Berkes, F., Lyver, P. O., \& Kislalioglu, M. (2004). Combining Science and Traditional Ecological Knowledge: Monitoring Populations for Co-Management. Ecology and Society, 9, 2. http://www.ecologyandsociety.org/vol9/iss3/art2

Olsson, P., Folke, C., \& Berkes, F. (2004). Adaptive Co-Management for Building Resilience in Social-Ecological Systems. Environmental Management, 34, 75-90. http://dx.doi.org/10.1007/s00267-003-0101-7

Rodríguez, I. (2007). Pemon Perspectives of Fire Management in Canaima National Park, Southeastern Venezuela. Human Ecology, 35, 331-343. http://dx.doi.org/10.1007/s10745-006-9064-7

Rodríguez, I. (2004). Conocimiento indígena vs científico: El conflicto por el uso del fuego en el parque nacional canaima, Venezuela. INCI, 29, 121-129. http://www.scielo.org.ve/scielo.php?script=sci_arttext\&pid=S0378-18442004000300005\&lng=es\&nrm=iso

Rodríguez, I., Leal, A., Sánchez-Rose, I., Vessuri, H., \& Bilbao, B. (2009). Facing up to the Challenge of Interdisciplinary Research in the Gran Sabana (Venezuela). Human Ecology, 37, 787-789. http://dx.doi.org/10.1007/s10745-009-9286-6

Rull, V. (2009). On the Use of Paleoecological Evidence to Assess the Role of Humans in the Origin of the Gran Sabana (Venezuela). Human Ecology, 37, 783-785. http://dx.doi.org/10.1007/s10745-009-9285-7

Toledo, V. M., \& Barrera-Bassols, N. (2008). La memoria biocultural. La importancia ecológica de las sabidurías tradicionales. Barcelona: Icaria Editorial.

Turner, N. J., Davidson-Hunt, I. J., \& O’Flaherty, M. (2003). Living on the Edge: Ecological and Cultural Edges as Sources of Diversity for Social-Ecological Resilience. Human Ecology, 31, 439-461. http://dx.doi.org/10.1023/A:1025023906459 